\title{
SEM PROTOCOLO
}

\section{"Holding", sim e não}

A aplicação, no Brasil, do modelo de "holding" das empresas estatais da Itália, tem vantagens e desvantagens, concluíram os técnicos italianos que participaram do seminário promovido pela Secretaria (Ministério) do Planejamento para discutir "As questões de controle de empresas estatais".

Entre as vantagens, os diretores do Instituto de Reconstrução Industrial da Itália, Giacomo Salvemini, Ugo Mazza e Duccio Valori, apontaram:redução significativa da divida, que, no caso italiano, passou de 37 bilhões de dólares em 1979 para 27 bilhões no ano passado; aumento da participação de capitais próprios, que, ainda no caso das empresas italianas, passou de 9 para 30 por cento.

As desvantagens são, entre outras, o risco de maior gigantismo, que poderia acabar por esconder mau gerenciamento; riscos de "desresponsabilização", por parte das empresas ligadas à "holding", com a criação de mais um nivel de decisão.

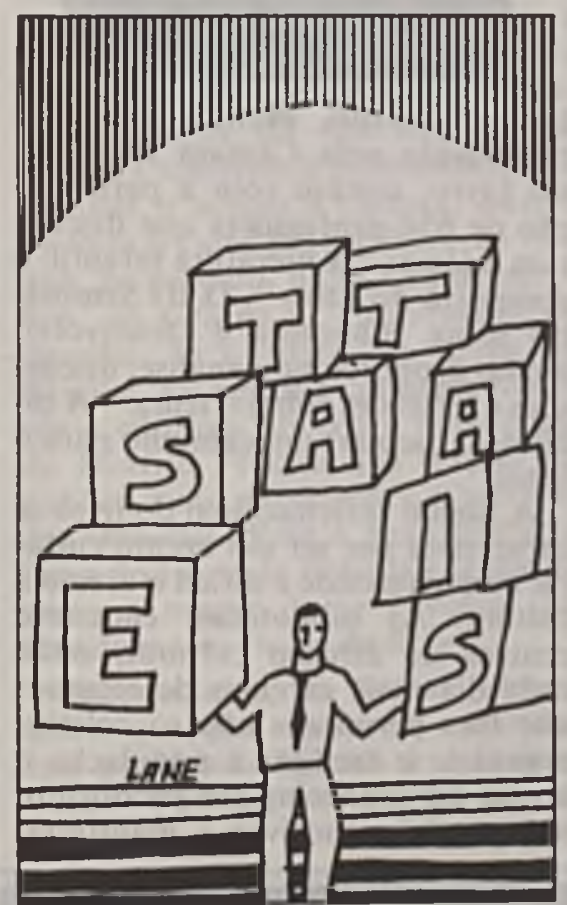

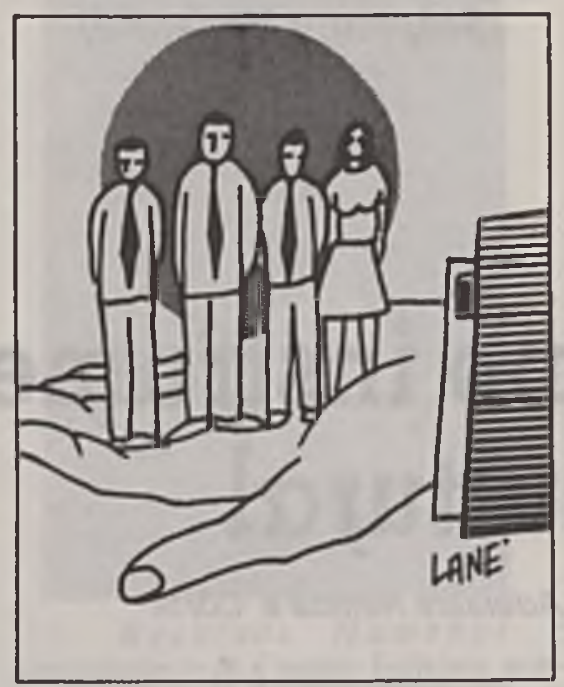

\section{BNDU chega, mas não dispensa}

A Empresa Brasileira de Transportes Urbanos, EBTU, irá mesmo fundir-se com o Banco Nacional de Habitação, para formar o novo Banco Nacional de Desenvolvimento Urbano, BNDU, confirmou o ministro do

Desenvolvimento Urbano, Deni Schwartz. Mas advertiu que não haverá demissões em função dessa mudança, porque "o problema do funcionalismo público federal, também nessa faixa, não é de quantidade e, sim, de distribuição".

-O que poderá ocorrer é um remanejamento e a possibilidade de atualizacão. Todos podem ter certeza de que a Nova República não está contra os funcionários garantiu o ministro Schwartz.

\section{Consultoria mais forte}

Decreto assinado pelo presidente José Sarney aumentou os poderes e atribuiçōes da Consultoria Geral da República. Além de assessorar diretamente o Presidente no terreno jurídico, caberá à Consultoria interpretar a Constituição, as leis e os atos do Governo para que sejam uniformemente seguidos pela administração pública.

Com a reformulação decretada pelo Presidente, cresce ainda mais o poder de influência dentro do governo do consultor Saulo Ramos.

A consultoria poderá, agora, sugerir ao Presidente e aos Ministros de Estado "a adoção de medidas, de caráter disciplinar, ou não, destinadas a apurar responsabilidades pelo descumprimento de diretrizes juridicas presidenciais" (Jornal de Brasilia, 8.7.86).

\section{Contratações congeladas}

O governo pretende manter, nos próximos anos, a proibição de contratacão de novos funcionários públicos. É o que se deduz da exposicão de motivos do ministro do Planejamento, João Sayad, que acompanha a proposta de orçamento plurianual de investimentos, encaminhada ao Presidente da República.

As despesas com pessoal e encargos sociais do governo não devem apresentar qualquer aumento real (acima da inflação) nos exercícios de 1988 e 89 , mantendo os mesmos valores de 1987, ou seja, ficarão em torno de CzS 110 bilhőes.

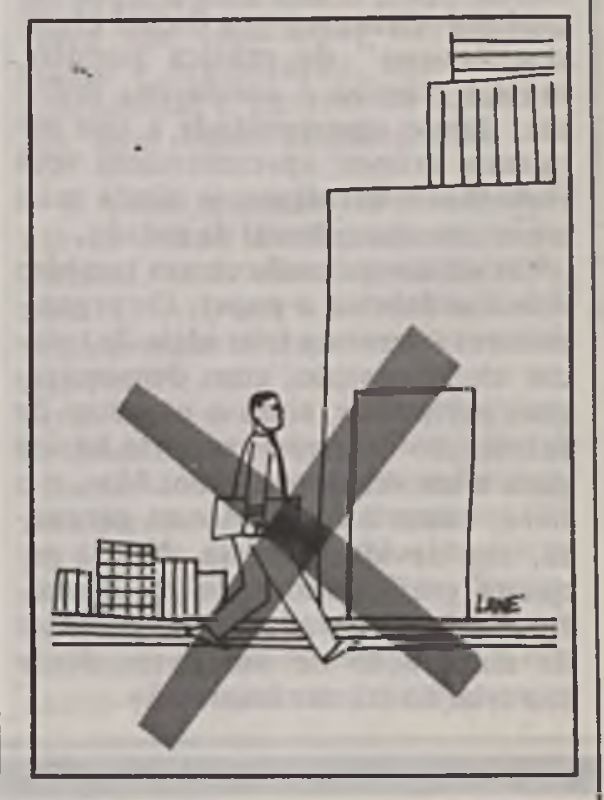

